\title{
Study on Enterprise Education System for Undergraduates in Universities
}

\author{
Min Zhang ${ }^{1}$ \\ ${ }^{1}$ School of Economics and Science, Chang Chun University of Science and Technology, Chang Chun, China \\ Correspondence: Min Zhang, School of Economics and Science, Chang Chun University of Science and \\ Technology, Chang Chun, 130000, China. Tel: 86-1390-4310-731. E-mail: zmzs10118@163.com
}

Received: September 15, 2014

Accepted: October 2, $2014 \quad$ Online Published: November 19, 2014

doi:10.5539/hes.v4n6p58

URL: http://dx.doi.org/10.5539/hes.v4n6p58

\begin{abstract}
This paper studies the higher school undergraduate entrepreneurship education system. Its architecture mainly includes five aspects of content, improve the students' entrepreneurial cognitive ability, adjust the teacher's education idea, carry out various kinds of entrepreneurship and entrepreneurial training, carry out flexible forms of team learning organization, and strengthen the attention of colleges and universities for undergraduate entrepreneurship.
\end{abstract}

Keywords: undergraduates, entrepreneurship, the education system

\section{Introduction}

Enterprise education is an internationally advanced educational ideology and an emerging practice of education reform. As a new educational philosophy, enterprise education was first proposed by Dr. Colin Bor (2004), an American scholar. Its purpose was to foster talents with entrepreneurial awareness, pioneering spirit and entrepreneurial ability. Enterprise education in China's universities first began in 1997 when Tsinghua University organized the "Tsinghua Innovation Plan Competition". Then it was popularized to the whole country in 1999. In 2002, the Ministry of Education officially included enterprise education into pilot student training program in nine universities, including Tsinghua University, Beihang University, Shanghai Jiaotong University, Northwestern Polytechnical University, Heilongjiang University, Nanjing University of Finance \& Economics, Renmin University of China, Xi'an Jiaotong University, and Wuhan University. After a long time of development, enterprise education has embarked on the path of formal education in China, undergoing different levels of development in universities. However, compared with developed countries, enterprise education started late in China's universities, which has a lower level of maturity and has not yet formed a mature architecture. This study starts from the establishment of enterprise education for undergraduates in universities, hoping to provide advice for its better development in China.

\section{Establishment of Enterprise Education System for Undergraduates in Universities}

A Chinese scholar Peng Yunfei once said "enterprise education for undergraduates is a complicated systematic program involving the whole education process and all aspects of society, specifically, educational ideology, management system, operational mechanism, training program, teaching content, teaching methods, educational environment, and educational atmosphere". Enterprise education mainly involves three parties, i.e. students, teachers and school managers. Only when these three parties cooperate and coordinate mutually will enterprise education be able to be carried out in universities. The author believes that enterprise education system for undergraduates in universities can be established from the following five aspects:

1) Improving students' cognition on entrepreneurship.

In order to establish enterprise education system for undergraduates, we need to help them to improve cognition on entrepreneurship and cultivate their ability of rational analysis according to students' respective characteristics. The main task is to change their entrepreneurial ideas and encourage them to take entrepreneurship as one employment choice in the future. We should change their concept of employment from the traditional passive concept of "relying on others and waiting and asking for jobs" to a more aggressive concept that "I want to start my own business". Meanwhile, it is also necessary to cultivate in students a good altitude and right starting point towards entrepreneurship: entrepreneurship is not asking for the moon but should 
start from the small and develop gradually; besides, entrepreneurship is not to show off. The students should develop a sense of social responsibility.

As early as freshman enrollment, universities can set up "Career Planning" and other courses to provide knowledge on entrepreneurship in freshman education. This can give students a preliminary understanding of entrepreneurship and a clear understanding on their own strengths and weaknesses. This can also foster a preliminary entrepreneurial awareness. It should be made clear that early enterprise education is not to ask each student to create a business, but to enable them to understand the key issues, inherent law and risks, and problems that may be encountered by imparting knowledge related to business to students and help them do rational planning for future careers. The purpose at this stage is to foster "prospective entrepreneurs" and "entrepreneurial habits of mind". After admission, according to the characteristics of each grade, universities can provide a better and broader platform for students who have entrepreneurial ideas by arranging selective courses, organizing entrepreneurship competition, etc. Meanwhile, universities should actively grasp market information and adjust teaching content to provide students with up-to-date knowledge on future entrepreneurship.

In addition, they should change their concept of employment. In the era of higher education popularization, along with the increasing employment pressure, the structural contradictions of employment are more pronounced and employment situation is grim. In this case, undergraduates should not rely on the society to provide jobs for them but should actively start their own businesses according to their respective characteristics, interests and capacities. Entrepreneurial awareness should be indoctrinated as students' self-development goals and become the driving force for their entrepreneurial desire. A change in the concept of employment will facilitate further development of enterprise education.

2) Adjusting teachers' educational philosophy.

The key responsibilities of teachers are "teaching the truth and skills and solving problems". Teachers are the most needed for building good schools. Most of the students' knowledge comes from teachers' words and deeds. Good teaching skills can ensure good teaching effects. Therefore, developing students' entrepreneurial ideas is inseparable with teachers' guidance and efforts; the practice of enterprise educational philosophy and realization of its goal also require an excellent team of enterprise education teachers. As a new educational philosophy, enterprise education not only reflects the connotation of quality education, but also highlights the spirit of innovation and entrepreneurial ability. In the United States, the schools which have achieved good effects of enterprise education hire "business mentors" from the outside. There are few full-time teachers in schools engaging in enterprise education. In China, Enterprise Education and Management Training School of Beihang University adopts this approach. The hired "business mentors" are the pioneering leaders in various industries. They have richer experience, so that they can provide students with more practical knowledge on entrepreneurship (Wang, 2006). The schools' employment of mentors from outside can, on one hand, make up for the disadvantages of school teachers in terms of hands-on experience; on the other hand, it increases the number of enterprise education teachers and improves the overall level of enterprise education.

To adjust teachers' educational philosophy, we need first to strengthen trainings for part-time and full-time enterprise education teachers to provide them with better teaching knowledge and skills and the opportunities to improve their overall capacity and qualifications. Many universities have cooperated with professional training institutions to carry out training for university teachers. Its main purpose is to train them on how to provide guidance for students' career planning as an early start.

The second purpose is to encourage them to change the traditional teaching mode from purely didactic into an interactive teaching mode. Enterprise education requires greater openness, flexibility and participation of both students and teachers. It advocates personalized teaching according to different characteristics of students. Enterprise education in universities is carried out in the whole university with each student as the potential object of education. Therefore, the universities must set up multiple educational goals according to different characteristics and requirements of students. In addition, other flexible teaching activities such as case studies and discussions should be carried out in class to stimulate students' enthusiasm for active learning and interest in entrepreneurship. It can also broaden their horizons and provide them with necessary knowledge on entrepreneurship. The more important purpose of enterprise education is to arouse students' desire for entrepreneurship and pioneering spirit.

3) Carrying out various forms of entrepreneurship courses and trainings.

Curriculum refers to the arrangement of various types of courses selected by certain universities, mainly including reasonable course structure and teaching content. Reasonable course structure means a rational structure between various courses, including reasonable course arrangement, reasonable order of opening 
courses, orderly connection between various courses, and provision of professional knowledge and ability acquired by students through learning and training in class. Enterprise curriculum will affect teaching effectiveness and also the development of teaching staff.

Entrepreneurship is a way of thinking and behavior, not just starting a company. The entrepreneurs should seize the opportunity, make the best use of resources, take risks, and create values. Entrepreneurship is not a scattered and random event, but has its intrinsic laws to be studied and understood. Enterprise education content can be organized in different ways according to different understandings of entrepreneurship. Universities in the United States and other developed countries started to carry out enterprise education in the late 1960s. Under the leadership of specialized agencies, a systematic and mature enterprise education curriculum had been designed and practiced ( $\mathrm{Li}, 2010)$.

China's universities should learn from foreign experiences in designing enterprise education curriculum and fully absorb the essence of various professional courses to optimize the combinations. Enterprise education curriculum should be a complete system, providing students with theoretical knowledge, and more importantly, the development of entrepreneurial skills. Students can develop their entrepreneurial skills through various forms of entrepreneurship trainings.

Entrepreneurship trainings are carried out according to practical requirements. Through various training activities, students are encouraged to participate in entrepreneurship activities. This embodies the cycle of coming from practice and going back to practice. Survey shows that the largest number of students wants to improve their entrepreneurial skills through participating in entrepreneurial practices. This indicates that students have realized that only by engaging in entrepreneurial practices can they effectively improve their entrepreneurial skills. Different from cultural classes, enterprise education requires students to participate in entrepreneurial practices to get real entrepreneurial knowledge and experience (Chai, 2010). Entrepreneurship training can cultivate their entrepreneurial courage and thinking, and enhance practical skills. First, entrepreneurship planning competition can be carried out in campus. Entrepreneurship planning competition is the most effective simulation activity for students, and plays a significant role in cultivating their entrepreneurial awareness and for them to accumulate entrepreneurial knowledge. Second, student entrepreneurial base can be established to provide a platform for exchange, communication and learning for students who are ready to start and have already started entrepreneurship. Students can also get support from the platform in the form of training, venture capital, projects, technology and hatching.

4) Flexible team learning can be carried out.

In the education sector, team learning is often named as cooperative learning, which is an ancient educational philosophy and practice. After experiencing primary and secondary school learning, university students have a more solid base of knowledge, have mastered certain learning methods and accumulated some life experience. They have developed the ability of independent thinking, which provides them a basic knowledge and ability for cooperative learning. Team learning is a suitable way for carrying out enterprise education for university students. In today's information explosion, it takes much time for a single person to acquire vast amounts of information and knowledge. Team learning can reduce the time spent by individuals through the mechanism of division of labor. Therefore, an individual can accumulate knowledge in a short time with a better effect.

In team learning, brainstorming approach can be adopted in discussion and each person can freely express their ideas on entrepreneurship. Through exchange, learning and inspiring, an original fuzzy idea can become clarified and a one-sided point of view can be corrected and improved to arrive at conclusions that are difficult to be obtained through individual thinking. By learning from other team members, students can broaden their horizons and learn new knowledge. Inside the team, the students are required to get along with different personalities, so that they exercise interpersonal skills. The team members also get the advantage of learning knowledge from others, which benefits their future development. The students with the teamwork awareness are more likely to achieve a successful career.

5) The attention from universities and schools to students' entrepreneurship should be enhanced.

As described above, the enterprise education system for university students should improve students' cognition on entrepreneurship, adjust teachers' educational philosophy, carry out various forms of entrepreneurship courses and trainings, and organize flexible team learning. These four aspects are inseparable from the concern and support from the universities for students' entrepreneurship. At present, enterprise education in China's universities is still at the infancy stage. Most universities do not have a sound incentive mechanism for entrepreneurial activities, and enterprise education curriculum has not been well promoted. So the universities are required to provide good guarantee for enterprise education. First, if conditions permit, universities should 
establish a special career guidance team composed of both disciplinary departments and administrations. In daily teaching and management, the disciplinary departments should pay attention to carrying out enterprise education in specialized courses, and to provide planned and purposeful guidance for students' entrepreneurial thinking.

Universities can also show concern and encouragement to enterprise education from the material and spiritual levels. University students do not have regular income. Their participation in entrepreneurship competition requires market research, research report writing, business plan development, or even trips to other places, which all require economic support. The best incentive for them is that universities provide good infrastructures, such as free computers and information centers, along with economic support such as covering the cost arising from students' participation in competition. At the spiritual level, universities can set the students with successful entrepreneurship as examples and give extra points in faculty appraisal and exemption from graduate entrance exams to stimulate their initiative and interest in entrepreneurship.

\section{Acknowledgements}

This work was financially supported by the youth fund of Chang Chun University of Science and Technology (XQNJJ-2011-14). I thank the sustentation fund for this article.

\section{References}

Chai, X. D. (2010). College students' entrepreneurship education based on tacit knowledge. Journal of east China normal university. Shang Hai.

Li, H. F. (2010). College students' entrepreneurship education research in China - entrepreneurship education by the ministry of education pilot colleges and lanzhou university as an example. Journal of Lanzhou University. Lan Zhou.

Peng, Y. F. (2004). Innovation in colleges and universities entrepreneurship education need to know a few questions. Journal of Hunan normal university education sciences. Hunan.

Wang, X. G. (2006). Analyses the main problems of college students' entrepreneurship education in China. Beijing: Chinese college students employment.

\section{Copyrights}

Copyright for this article is retained by the author(s), with first publication rights granted to the journal.

This is an open-access article distributed under the terms and conditions of the Creative Commons Attribution license (http://creativecommons.org/licenses/by/3.0/). 